\title{
Exchange Rate Appreciation, International Competitiveness And Purchasing Power Parity: The Shiomi Company Of Japan
}

\author{
John F. Boschen, College of William and Mary, USA
}

\begin{abstract}
In 2011 the ongoing appreciation in the yen against the US\$ led Japanese firm Shiomi to consider relocating its production facilities outside of Japan. As a prelude to making this decision, Shiomi commissioned an evaluation of the historical impact of the yen's appreciation on Japanese competitiveness. This evaluation is the basis for two important lessons in international financial management. First, it is the real exchange rate, rather than the nominal exchange rate, that determines the relative cost competitiveness of countries. Second, in accordance with the rules of purchasing power parity, the historical evaluation showed that higher inflation in the U.S. relative to Japan caused the ratio of Japanese to U.S. prices to fall at roughly the same rate as the yen's appreciation against the US\$. Thus the long-term appreciation in the yen had little impact on Japanese competitiveness. Students are asked to assess the relocation decision in light of the post-case data on exchange rates and consumer prices supplied in the case. The case is appropriate for use in an international financial management or international economics course.
\end{abstract}

Keywords: Purchasing Power Parity; International Competitiveness; Real Exchange Rate; Appreciation in the Yen

\section{INTRODUCTION}

C n 2011 the Shiomi Company, a Japanese manufacturer of microwave tower components, was concerned that the yen's ongoing appreciation against the US\$ was going to seriously impact the profitability of its business. Because Shiomi had a large presence in the U.S. market, much of the company's sales revenues were in US\$s. On the other hand, Shiomi's production facilities were located in Japan, so production costs were in yen. It was feared that continued appreciation in the yen would squeeze profit margins since that would mean US\$ revenues earned abroad would convert to fewer yen, making it to harder to cover costs.

The Shiomi Company of Japan produced transceivers and digital signal processors used in microwave towers. A large fraction of Shiomi's business was export driven, with the major U.S. cell phone service providers being important customers. The U.S. microwave components market was very competitive and buyers, usually large cell phone service providers, were sensitive to even small differences in price or contract terms. From Shiomi's point of view an implication of the competitive U.S. market was that the company felt it could not require payment in yen as part of a sales contract since U.S. firms preferred to pay in US\$s. If Shiomi insisted on payment in yen, a competitor could offer to accept payment in US\$s, and Shiomi would lose the business.

At the time Shiomi was not the only exporter concerned over the appreciation in the yen. Many other Japanese exporters also voiced alarm over the adverse impact of a rising yen on the international competitiveness of Japanese industries. As a 2011 article in The Wall Street Journal (2011a) stated,

"The yen's flirtation with record highs against the dollar has prompted a familiar worry from policy makers and Japan's auto and electronics makers, who complain that a strong currency wipes out profits and erodes competitiveness." 
Another article appearing in The Wall Street Journal (2011b) quoted the CFO of Toyota, Satoshi Ozawa, as saying,

"As CFO, I have to wonder about sticking to production in Japan. We've reached the limits of [profitable] Japan-based manufacturing at $¥ 80$ to the dollar."

\section{THE BUSINESS DECISION}

Shiomi's management felt it confronted an important business decision. Should the company move its manufacturing operations overseas, perhaps to the U.S., in order to avoid the potential impact of the continued appreciation in the yen?

As a prelude to making the relocation decision, Shiomi employed a team of consultants to evaluate the impact of the historical rise in the yen on the long-run international competitiveness of Japanese exports.

\section{EXCHANGE RATE BACKGROUND}

The nominal exchange rate, defined as the price of one currency in terms of another currency, is a highly visible economic variable that can directly impact the relative cost of producing in one country as opposed to another. The standard expression for the nominal exchange rate, $\mathrm{S}(\mathrm{US} \$(¥)$, is the number of US\$s per yen. For example, if the yen-US\$ exchange rate was S(US\$/ $¥)=$ US $\$ .01 / ¥$ then one yen would cost US $\$ .01$, or one cent. Other things equal, when the yen appreciates relative to the US\$ that means that it takes more US\$s to buy one yen. If the yen appreciates, say doubling in value, to S(US\$ $\$)=$ US $\$ .02 / ¥$, it would take US $\$ .02$ to buy a yen. Other things equal, from a U.S. importer's point of view, all Japanese exports would have doubled in price in terms of US\$s.

As part of the analysis of the impact of the appreciating yen, the team gathered data on the long-run behavior of the yen-US\$ exchange rate. Figure 1 is their graph of the exchange rate data through 2010.

Figure 1.

The Yen-US\$ Nominal Exchange Rate

1971- 2010

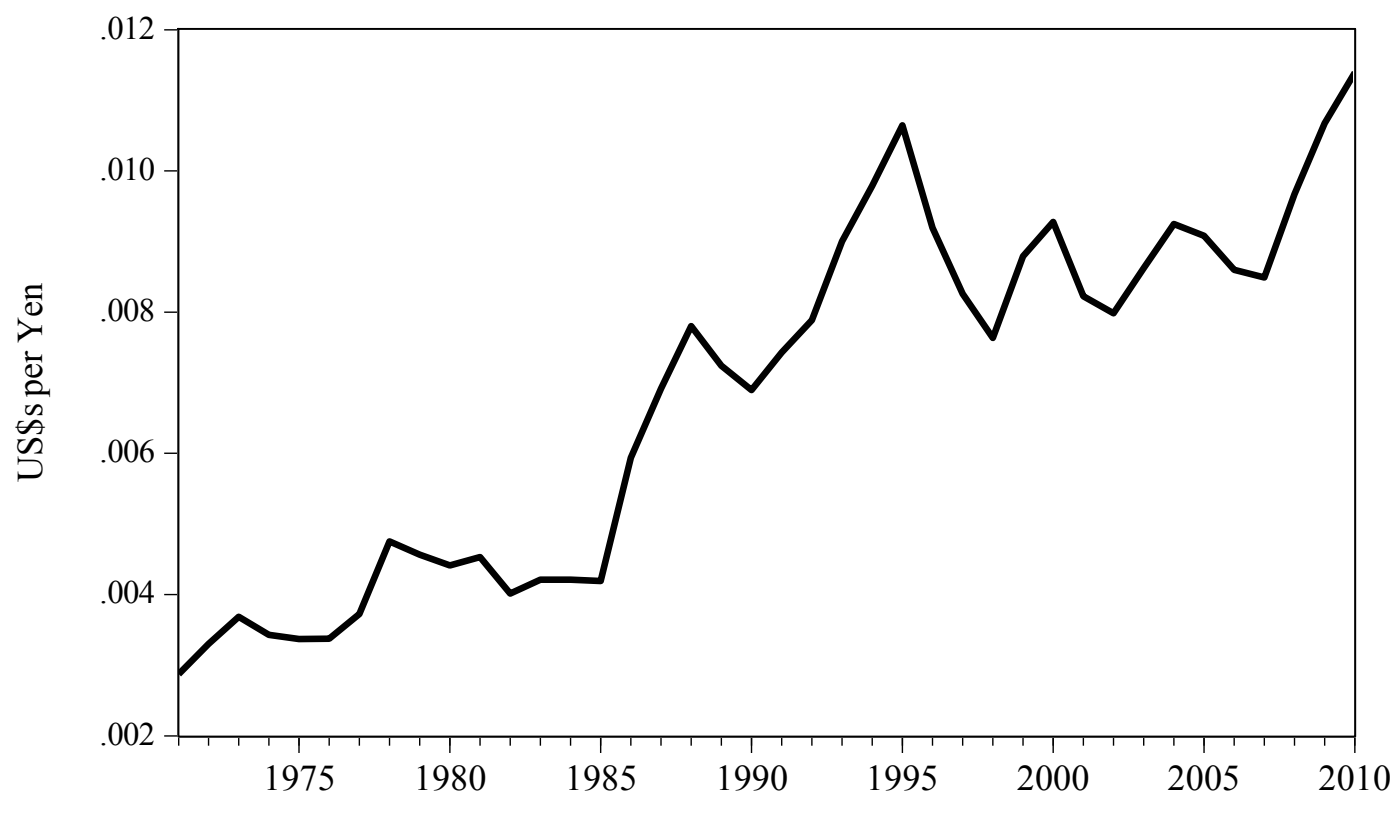

Source: Federal Reserve Bank of St. Louis FRED Database (2016). 
The team began their analysis of the yen-US\$ exchange rate in 1971, the year that Japan left the Bretton Woods fixed exchange rate system. ${ }^{1}$ In that year the yen became a "floating" exchange rate currency whose value was determined in the foreign exchange markets. The team saw that the history of the yen-US\$ exchange rate since 1971 was one of an ongoing long-term appreciation in the yen relative to the US\$. True, as the figure shows, the yen's most dramatic rise was from 1971 through 1995 when the yen appreciated 360 percent against the US\$. However, while the appreciation since 1995 was milder and more intermittent, the value of the yen relative to the US\$ by 2010 was the highest it had ever been at 396 percent above the 1971 level. ${ }^{2}$ Little wonder that Shiomi was concerned about its ability to remain competitive in the international markets.

\section{THE EXPORT PUZZLE}

The team next looked at Japan's export sector to gage the impact of the yen's appreciation on overall export demand. Since the yen had appreciated almost 400 percent, it might be expected that Japanese exports would have suffered as the yen's price in terms of US\$s rose. The team's graph of Japanese exports 1971-2010 is shown in Figure 2 .

Figure 2.

Japanese Exports adjusted for Inflation, 1971-2010

(in Trillions of Yen)

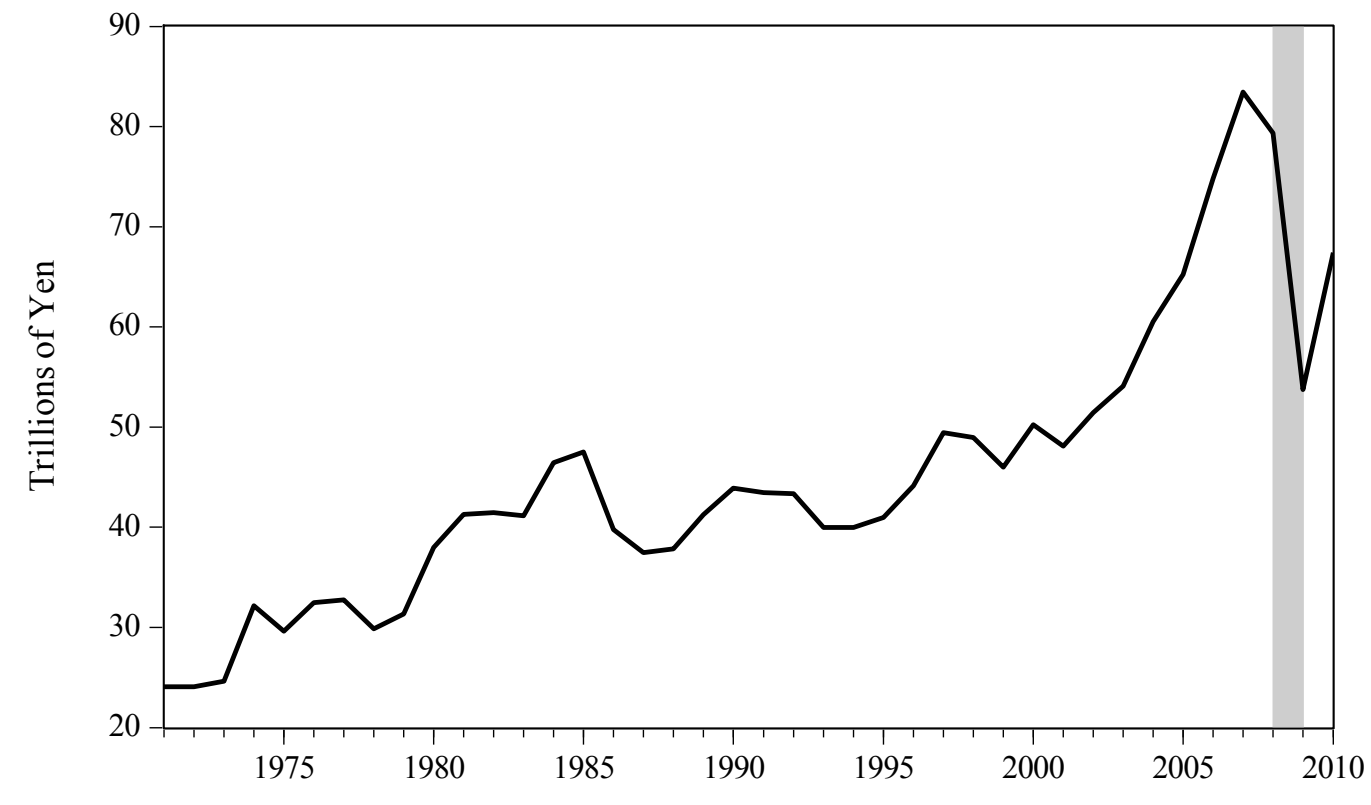

Source: Federal Reserve Bank of St. Louis FRED Database (2016).

Surprisingly the export data showed that, instead of declining, the Japanese export sector had consistent, robust growth since 1971. Although exports fell in 2008 and 2009, that anomaly was more likely the result of the worldwide Great Recession (shown in gray in the figure) and exports began to rebound in 2010. Somehow, the appreciation in the yen had not had an obvious, large impact on the Japanese export sector.

\footnotetext{
${ }^{1}$ Bretton Woods was an exchange rate system imposed after World War II in which all the major free-market economies had their currencies pegged at a fixed value relative to the US\$. The yen was part of the Bretton Woods system. Over time, fixed exchange rates became harder to maintain and in 1971 the Bretton Woods system was abandoned by the major economies. After 1971 the major economies let the foreign exchange market determine the exchange rate between currencies under a system of 'floating' exchange rates. The floating rate system prevails today.

${ }^{2}$ All data in this case are available in excel spreadsheet form on request to the author.
} 


\section{THE REAL EXCHANGE RATE}

The team decided to look more deeply into the impact of the yen's appreciation on Japanese competitiveness. To do this they turned to a tool useful for examining international competitiveness, the real exchange rate. The real exchange is defined as the nominal exchange adjusted for the relative price of production in both countries. The usefulness of the real exchange rate is that it summarizes how both the exchange rate and the relative costs between two countries impact a country's competitiveness. That is, while the nominal exchange rate does affect cost competitiveness, it is not the only factor involved. Relative costs of production also matter. In general the cost of producing goods and services in a given country is higher with higher labor costs, a higher cost of capital and higher raw materials costs. On the other hand, the more productive are workers and the more efficiently capital is used in the production process, the lower are overall production costs per unit of output produced.

The expression for the Japanese real exchange rate relative to the U.S. is

$$
\varepsilon(\text { Japan }) \equiv \mathrm{S}(\mathrm{US} \$ / ¥) \cdot \mathrm{P}(\text { Japan }) / \mathrm{P}(\mathrm{U} . \mathrm{S} .)
$$

$\mathrm{S}(\mathrm{US} \$ \#)$ is the nominal exchange rate in US\$s per yen. $\mathrm{P}(\mathrm{Japan})$ is the average level of prices for goods and services in Japan, while P(U.S.) is the average level of prices for goods and services in the U.S.

As a single product example, suppose that $\mathrm{S}(\mathrm{US} \$(¥)$ is one cent per yen or US\$.01/¥. Also suppose that the average price of a cell phone produced in Japan is $¥ 10,000$ while the average price of a very similar cell phone produced in the U.S. is US\$100. Plugging these values in the Japanese real exchange rate we get

$\varepsilon(\mathrm{Japan})=\mathrm{S}(\mathrm{US} \$(¥) \cdot \mathrm{P}(\mathrm{Japan}) / \mathrm{P}(\mathrm{U} . \mathrm{S})=.\mathrm{US} \$ .01 / ¥ \cdot(10,000 ¥ / \mathrm{US} \$ 100)=1.0$.

The US\$ currency signs in the numerator and denominator cancel out, as do the $¥$ currency signs in the denominator and the numerator, so there are no currency signs attached to a real exchange rate.

A value of $\varepsilon($ Japan $)=1.0$ is referred to as Purchasing Power Parity (PPP). What does that mean? It means that the price of a cell phone in Japan and the price of a cell phone in the U.S. are the same, after adjusting for the nominal exchange rate. In principle a customer could take US $\$ 100$ that would buy a U.S. cell phone, exchange it for $¥ 10,000$ at US\$.01 per yen, and then use the $¥ 10,000$ to order a Japanese cell phone. In effect both the U.S. and Japanese cell phones have the same exchange-rate-adjusted price when $\varepsilon=1.0$.

If the yen were to appreciate, say double in value, to US\$.02 per yen, then the real exchange rate would go up as well to

$\varepsilon(\mathrm{Japan})=\mathrm{US} \$ .02 / ¥ \cdot(10,000 ¥ / \mathrm{US} \$ 100)=2.0$.

The increase in the real exchange rate to 2.0 indicates that exchange-rate-adjusted prices are twice as high in Japan relative to the U.S. Now the US $\$ 100$ that could buy a U.S. cell phone will only exchange for $¥ 5,000$, not enough to buy a Japanese cell phone selling for $¥ 10,000$. If a U.S. resident wanted to order a Japanese cell phone, he or she would have to spend US $\$ 200$ to acquire the $¥ 10,000$ needed to make the purchase. At $\varepsilon(\mathrm{Japan})=2.0$, Japan’s cell phone makers would be at a distinct cost disadvantage.

An important implication of PPP is that over time the exchange-rate-adjusted price of traded goods between two countries should gravitate towards parity, or $\varepsilon=1.0$. If the real exchange rate for Japan were 2.0, so that Japan had a cost disadvantage, either the yen would depreciate or the price of producing in Japan would fall as exporters bought more U.S. cell phones and fewer Japanese cell phones. For example, if the price of cell phones in Japan fell to $¥ 5,000$ while the U.S. price remained at US $\$ 100$, then the fall in the relative cost of producing cell phones in Japan would push the real exchange rate back towards 1.0. 


\section{PRICES AND INFLATION IN JAPAN AND THE U.S.}

The team turned its attention to prices in Japan relative to the U.S., $\mathrm{P}(\mathrm{Japan}) / \mathrm{P}(\mathrm{U} . \mathrm{S}$.). While it was true that the yen appreciated in nominal terms, perhaps the prices of Japanese goods and services fell relative to the U.S. prices which would make the ratio $\mathrm{P}(J a p a n) / P($ U.S.) decline. If the price ratio fell enough to offset the appreciation in the yen, that might explain the export puzzle. Exports could have remained strong because although the nominal exchange rate appreciated, the real exchange rate did not.

The most comparable broad-based average price measures available since 1971 for the U.S. and Japan are their consumer price indices (CPI). ${ }^{3}$ These indices measure the cost of a market basket of goods and services purchased by a representative economic unit such as a family (U.S. CPI) or an individual (Japanese CPI). Using this data the team graphed the ratio, CPI(Japan)/CPI(U.S.), from 1971-2010. Figure 3 shows this graph. In the figure the base year for the price ratio is 1971 and the price ratio in that year is set to 1.0. All price ratios in subsequent years are relative to 1.0. A price index ratio of .60 in 2006 means that prices in Japan were only 60 percent as high as in the U.S. as compared to the 1971 price ratio.

Figure 3.

Japanese to U.S. Average Price Ratio, 1971-2010

(Japanese CPI/U.S.CPI)

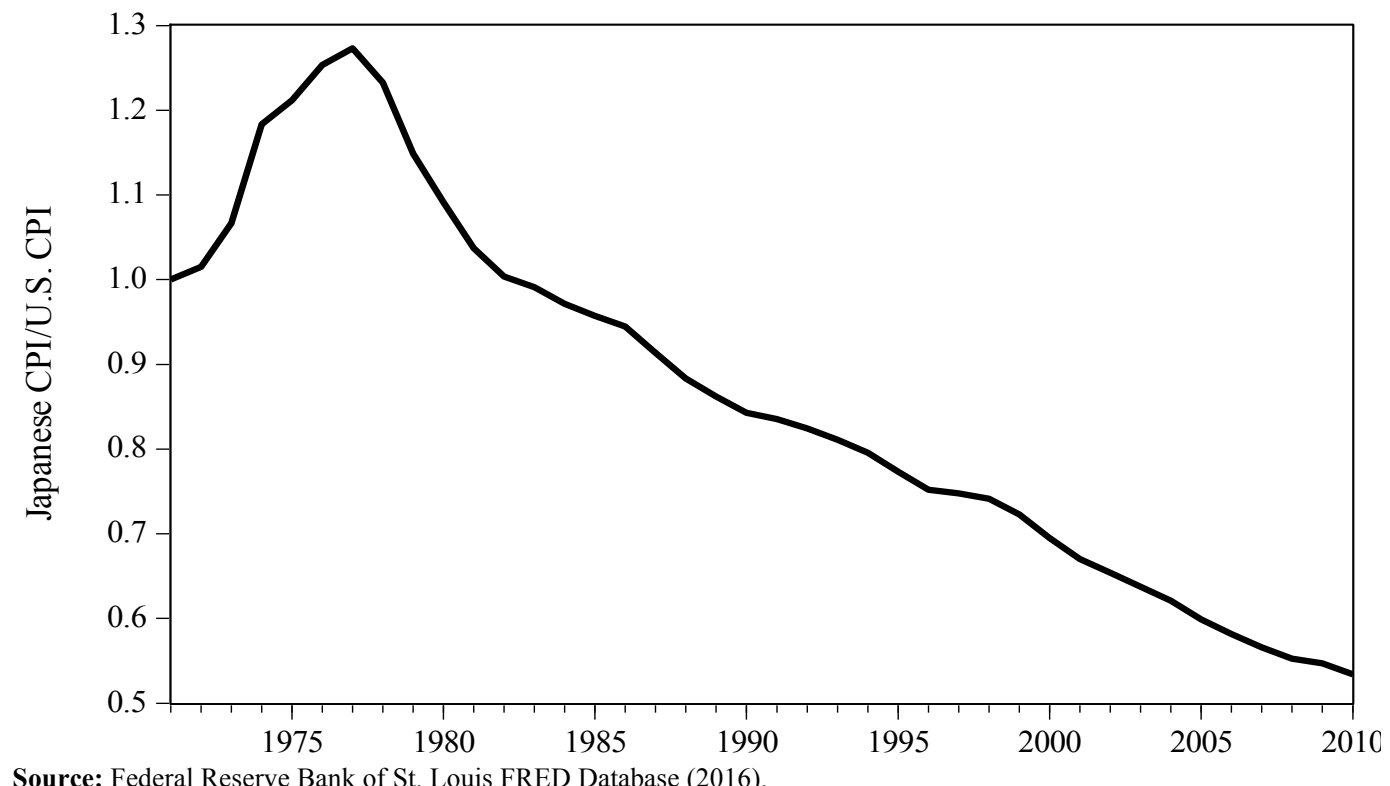

As Figure 3 shows, average prices in Japan relative to those in the U.S. have been declining since the late 1970s. In fact, by 2010 average prices in Japan relative to the U.S. had fallen to 55 percent of the 1971 level. The answer as to why there had been strong export performance in spite of the appreciating yen was becoming clear. While the yen had been appreciating relative to the US\$, the second component of the real exchange rate, P(Japan)/P(U.S.), had been falling.

The team found the cause of the decline of the relative prices in Japan was the different inflation experience of the two countries. If prices were rising slower in Japan than in the U.S. because Japan's inflation was lower, that would cause the CPI price ratio, CPI(Japan)/CPI(U.S.), to fall over time. The team graphed the inflation histories of the two countries since $1971 .^{4}$ The results are shown in Figure 4.

\footnotetext{
${ }^{3}$ An aggregate producer price index for Japan that is comparable to the U.S. producer price index (for all commodities) was not available back to 1971.

${ }^{4}$ The Annual CPI Inflation Rate $\equiv 100 \cdot(\mathrm{CPI}$ (this year) - CPI(last year))/CPI(last year) for each country. The annual CPI data are the average of monthly data over a given year.
} 
Figure 4.

U.S. Versus Japanese Inflation, 1971-2010

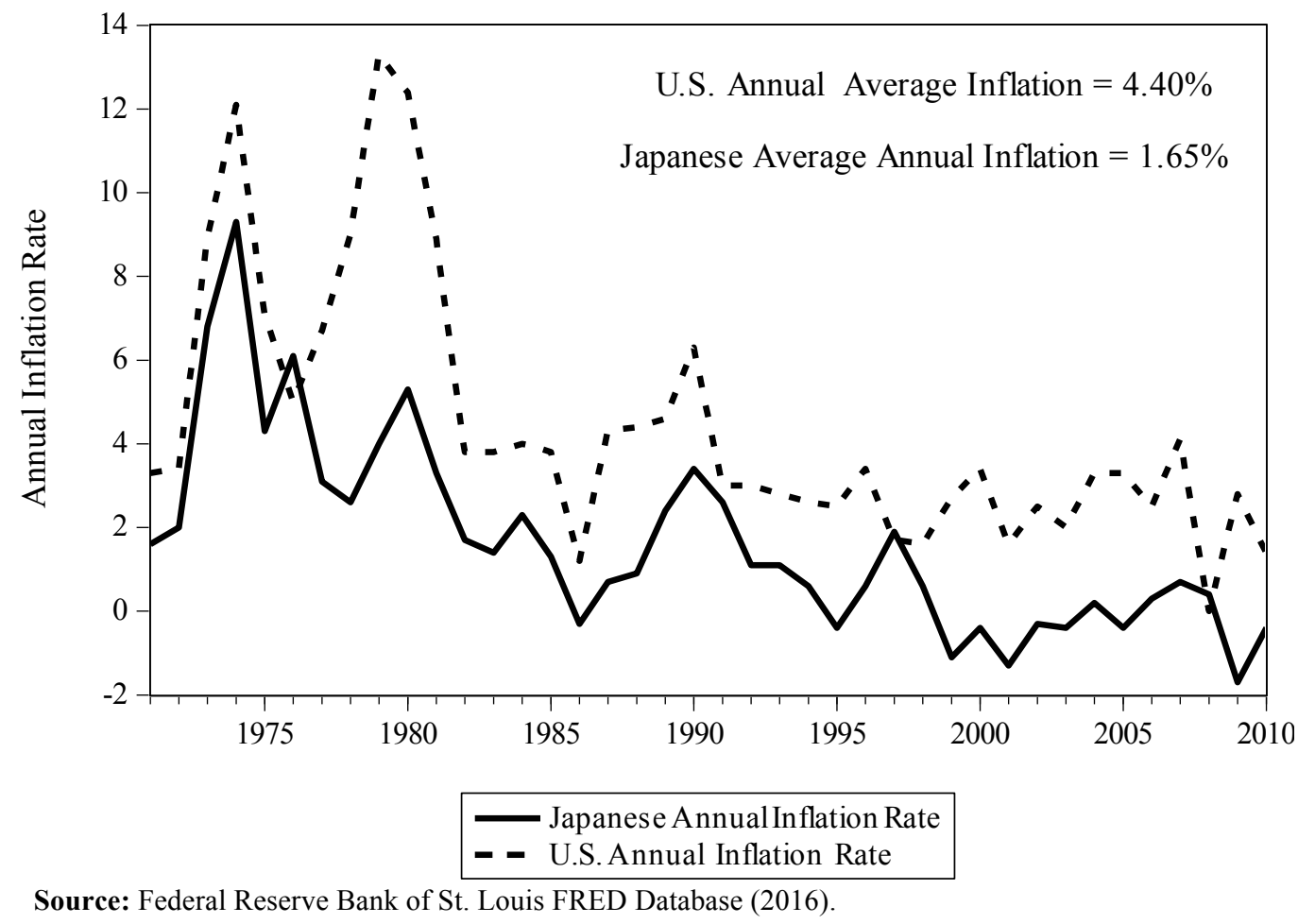

Figure 4 showed Japan's annual inflation rates were almost always below U.S. inflation rates. Inflation averaged about 1.65 percent annually in Japan whereas the U.S. experienced an annual inflation rate of 4.4 percent. Clearly the faster increase in prices in the U.S. due to higher inflation acted to reduce P(Japan)/P(U.S.) over time and offset the appreciation in the yen.

But how much did the higher U.S. inflation actually offset the impact of the yen appreciation on the real exchange rate? The team combined the CPI and exchange rate data using the real exchange rate formula in equation (1) to construct the Japanese real exchange rates shown in Figure 5. The Figure shows that the present day Japanese real exchange rate is indeed higher than in the 1970s, appreciating substantially through 1995 . This is the same time frame over which the appreciation in the yen-US\$ nominal exchange rate was greatest. However, over the most recent fifteen years, 1995-2010, the real exchange reversed course and fell. In fact the Japanese real exchange rate had declined by 26 percent since 1995. Japanese economic competitiveness, as measured by the real exchange rate, was stronger in 2010 than in the 1990s. 
Figure 5.

Japanese Real Exchange Rate*

$\varepsilon($ Japan $)=\mathrm{S}(\mathrm{US} \$ ¥) \cdot \mathrm{P}(\mathrm{Japan}) / \mathrm{P}(\mathrm{U} . \mathrm{S}$.

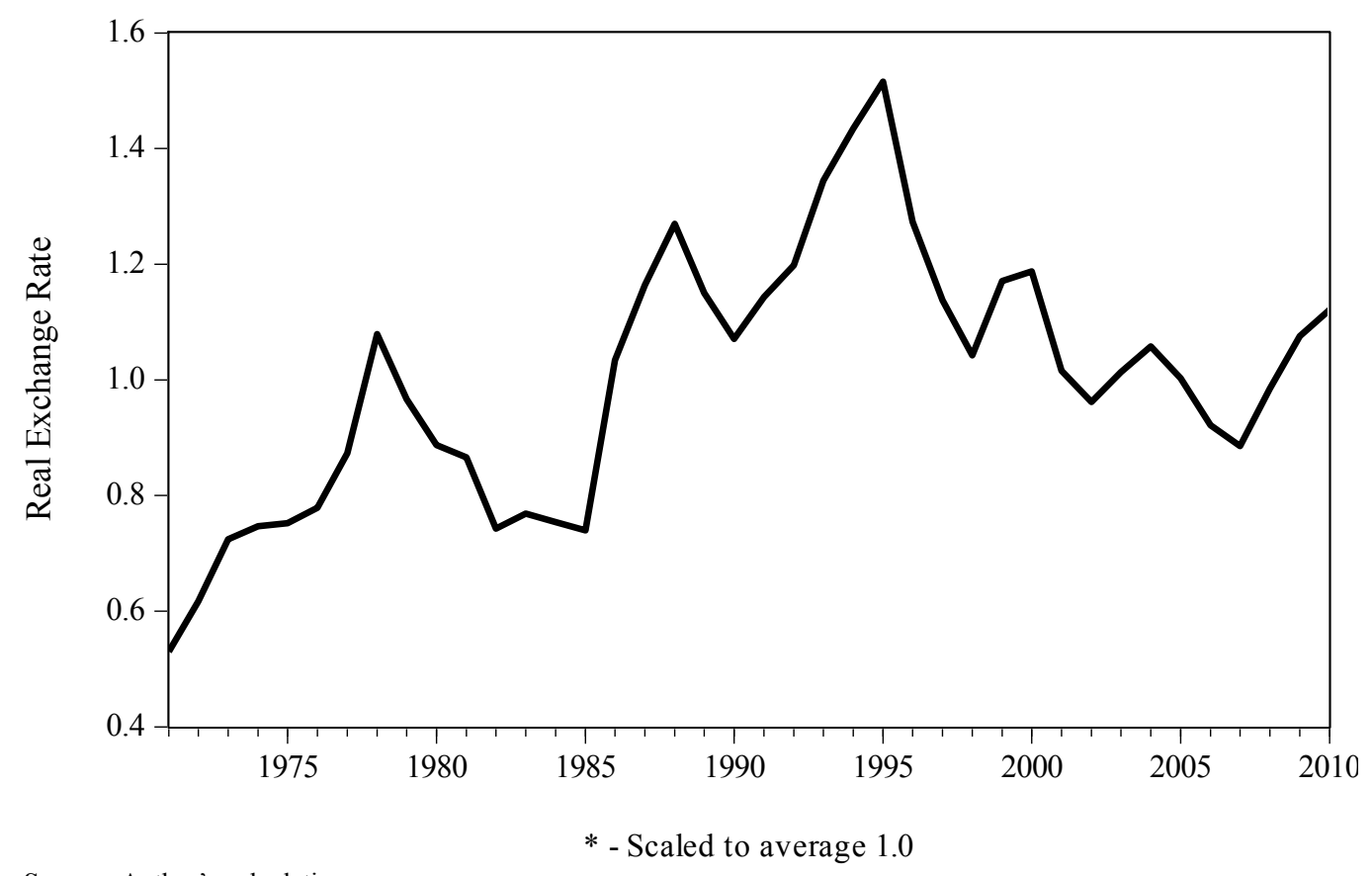

Source: Author's calculations.

PURCHASING POWER PARITY AND THE REAL EXCHANGE RATE

The consultants realized that their recommendation depended on what they thought the real exchange rate might do in the future. Indeed, Figure 5 showed an appreciation in the real exchange rate over 2008-2010. Would it continue? At first assessing the long-run future of the real exchange rate looked to be a difficult task since the future trend in the Japanese real exchange rate depended on three factors: the nominal exchange rate, the Japanese inflation rate and the U.S. inflation rate. Any one of these variables would be hard to forecast accurately, let alone all three. However, as the consultants pointed out in their report, the history of the Japanese real exchange rate reveals a very important tendency which is a characteristic of PPP. It is that over long periods of time the Japanese real exchange rate had a propensity to eventually increase when it was below one, and tended to eventually decrease when it was above one. ${ }^{5}$ This behavior is the hallmark of PPP which says that over time the real exchange rate should tend toward one.

How does PPP work? When inflation in the U.S. is higher than in Japan, prices in the U.S. eventually become higher than those in Japan. U.S. goods and services would no longer be cost competitive when compared to Japanese products. International buyers would buy more of the cheaper Japanese products, increasing the demand for yen, and buy less of the expensive U.S. products, decreasing the demand for US\$s. The resulting increase in demand for yen would cause the yen to appreciate, or said conversely, the resulting decrease in demand for US\$s would cause the US\$ to depreciate. The depreciation in the US\$ would offset the increase in US\$ prices due to inflation. PPP thus suggests that the currency of a low-inflation country will eventually appreciate relative to the currency of a high-inflation country by the difference in the two inflation rates. In the case of the U.S. and Japan, the U.S. is the high-inflation country at 4.40 percent and Japan is the low-inflation country at 1.65 percent. The difference, $4.40 \%$ $-1.65 \%=2.75 \%$, should be the annual average appreciation in the yen over 1971-2010. In fact the annual average rate of appreciation in the yen was 2.52 percent over this period.

${ }^{5}$ See Bekaert and Hodrick $(2012,257-265)$ for a comparison of actual yen-US\$ exchange rates with the yen-US\$ exchange rates implied by PPP. A more in-depth statistical analysis of PPP dynamics is Imbs et al. (2005). Perhaps the most well-known application of PPP is The Economist magazine's Big Mac Index. Recent values of this index are found in The Economist (2015). 


\section{RECOMMENDATION AND CONCLUSION}

The team concluded that the historical appreciation in the yen was primarily due to the fact that U.S. inflation was consistently higher than Japanese inflation. Therefore, while Shiomi might benefit by moving its operations to the U.S. to avoid the effects of an appreciating yen, that benefit would be offset by the fact that over time production costs would rise more quickly in the U.S. than in Japan. The team also concluded that if Japan and the U.S. managed to have the same or similar low rates of inflation in the future, then the yen would stop appreciating thus removing the need to move operations to the U.S.

Therefore, the consultants' recommendation, which the company accepted, was that Shiomi not move operations to the U.S. but instead employ basic currency hedging techniques to reduce short-run exposure to currency fluctuations.

\section{POST-CASE ANALYSIS}

It is five years after the consultants' recommendation that Shiomi not move its production facilities from Japan. The consultants' recommendation was based on the argument that the real exchange rate was stable over time. Because historically PPP seemed to hold over time, moving production operations would not, on net, gain anything since whatever advantages that would accrue to avoiding higher costs due to appreciation in the yen would be lost to rising production costs in the U.S.

But did the real exchange rate behave as the consultants thought it would in the intervening years? You can now examine what actually happened after 2010. The data in Table 1 below are for the yen-US\$ exchange rate, the U.S. CPI and the Japanese CPI for the years 2010 through $2015 .^{6}$

Table 1. Post-2010 Data

\begin{tabular}{c|c|c|c}
\hline Year & $\begin{array}{c}\text { Exchange Rate } \\
\text { in US\$s per } \mathbf{z}\end{array}$ & U.S. CPI & Japanese CPI \\
\hline 2010 & 0.0114 & 2.921 & 3.013 \\
\hline 2011 & 0.0125 & 3.076 & 287.8 \\
\hline 2012 & 0.0125 & 3.121 & 286.9 \\
\hline 2013 & 0.0102 & 3.171 & 297.9 \\
\hline 2014 & 0.0095 & 3.174 \\
\hline
\end{tabular}

Source: Federal Reserve Bank of St. Louis FRED database (2016).

With the data in Table 1 and the formula for the Japanese real exchange rate in equation (1), use excel or another spreadsheet to calculate the real exchange rate for the years 2010 through 2015. Make a chart of the real exchange rate with years on the horizontal axis and the real exchange rate on the vertical axis, as in Figure 5.

\section{Case Questions:}

1. Using the definition of inflation in footnote 4, calculate the annual Japanese and U.S. inflation rates for 2011 through 2015. Did Japanese inflation remain lower than U.S. inflation post-2010?

2. Did the yen continue to appreciate against the US\$ in nominal terms after 2010 ?

3. PPP implies that if two countries have similar inflation rates then the nominal exchange rate should remain stable, neither appreciating nor depreciating. Was this true for Japan and the U.S. after 2010?

4. Did the real exchange rate appreciate (raising Japanese costs) or depreciate (lowering Japanese costs) post-2010? Did the consultants' advice, based on PPP work out?

\footnotetext{
${ }^{6}$ In Table 1 the U.S. CPI data is scaled to imply an average Japanese real exchange rate, $\varepsilon(J a p a n)$, equal to one over the 1971-2010 period. 


\section{AUTHOR BIOGRAPHY}

John F. Boschen is Brinkley-Mason Professor of Economics and Finance at the Raymond A. Mason School of Business, College of William and Mary. He received his Ph.D. in Economics from Brown University. He served as an economist at the Board of Governors of the Federal Reserve System and has been Visiting Scholar at the Federal Reserve Banks of Kansas City and Richmond. His research interests include international finance and monetary policy. He has published over two dozen articles in such journals as the Journal of Money Credit and Banking, the Journal of Monetary Economics and The Accounting Review.

\section{REFERENCES}

Bekaert, G., \& Hodrick, R. (2012). International Financial Management. $2^{\text {nd }}$ Edition. Boston: Pearson.

Federal Reserve Bank of St. Louis (2016). FRED Economic Database, https://research. stlouisfed.org/fred2/

The Economist (2015). The Big Mac Index: A Few Dollars More. July 15.

Imbs, J., Mumtaz, H., Ravn, M., \& Rey, H. (2005). PPP Strikes Back: Aggregation and the Real Exchange Rate. Quarterly

Journal of Economics, 120(1), 1-43.

Wall Street Journal (2011a). Strong Yen Sparks National Debate, August 15.

Wall Street Journal (2011b). Toyota says Strong Yen Affects Operations, May 11. 


\section{NOTES}

